\title{
Research on the Innovation of Art Education Methods in Colleges and Universities at Micro-times
}

\author{
Zhiyuan Yan \\ Henan University of Animal Husbandry and Economy, Zhengzhou, Henan, China, 450046
}

\begin{abstract}
Keywords: Innovation, Art Education Methods, Colleges and Universities, Micro-times
Abstract. "Micro-age" is a "new" network that contains information dissemination, individual communication way, life style and other forms. In light of the existing problems, the micro-age art education and management in colleges and universities should strengthen the innovation, take cultivate the innovative talents as the main line, set up the open education management idea, strengthen the teachers' construction and strict management system.
\end{abstract}

\section{Introduction}

"Micro-era" is a new network space taking micro-information, micro-media, micro-community as the main form. It is based on the modern electronic devices such as mobile phones and PDAs, and shapes the way of personal life experience and thinking in the network system, such as micro-payment, micro-creation and micro-reading. College art education can effectively improve the overall quality of the students, at present, the traditional concept of art education, education content and education methods need to be further improved. Therefore, in the specific implementation, it is necessary to promote the standardization of art education and standardization, but also to combine the background of the development of the times, and an accurate understanding of social demand for talent standards.

\section{The Using Status of Student Network in Micro-Times}

Micro-Blogging Becomes A Gathering Place for College Students. The network has evolved from a tool for initial information delivery to a new way of communication between people. In addition to the general characteristics of openness, interactivity and immediacy, the micro-blog has the characteristics of convenient operation, concise content, distinct personality, information sharing and interactive interaction, which attracts extensive use of college students. I selected 600 students from Zhejiang Normal University to conduct a sample survey. The results showed that $74.8 \%$ of the students opened the micro-blog, $21.3 \%$ of the students ready to open micro-blogging recently, only $3.9 \%$ of students said not interested in micro-blogging; Bo students, $39 \%$ of students use micro-blogging time is not fixed, $5 \%$ of students use micro-blogging every day for more than 1 hour, $10 \%$ of students use micro-blogging every day for half an hour to 1 hour; "micro-blogging on their own lives Impact "of the survey, $4.76 \%$ of students said that life cannot be without micro-blogging, $20.11 \%$ of students said micro-blogging is an important role, $47.09 \%$ of students think that no micro-blogging life will be a lot less fun.

Micro-Blogging Has Become A Communicating Platform for College Students.Micro-blogging broke the fixed Internet and mobile Internet restrictions, to achieve the integration of computers and mobile terminals, so that the content of the propagation speed than other media more convenient and faster. A survey of the use of micro-blogging found that college students in the "attention to friends", the concern around the students friends accounted for $79.47 \%, 67.37 \%$ concerned about the star idol, concerned about the official micro-blogging accounted for $60.53 \%$, concerned about the campus celebrities accounted for $42.63 \%$, The attention of teachers or counselors accounted for $11.58 \%$; in the "content release", often write personal feelings accounted for $71.05 \%$, reposted elsewhere accounted for $68.95 \%$, comment on all kinds of news events accounted for $43.68 \%$, published his ideas Accounting for $18.95 \%$; on the location of choice to update the micro-blogging, accounting for $77.37 \%$ in the bedroom, in the campus leisure 
entertainment accounted for $38.95 \%$ in the classroom $17.37 \%, 8.95 \%$ in the study room. Can be found, micro-Bo because of its one-on-one, one-to-many, many-to-many exchange interaction mechanism, at any time, any time broadcast, attention, forward and comment on relevant information, record their feelings and insights, life in the harvest and experience, opened up a large platform for college students online communication.

Micro-Blogging Has Become the Spiritual Home of College Students. The rapid development of the network has changed people's life style and living environment. Contemporary college students are under the influence of the network environment, the growth of the students and the spirit of the world and interpersonal way compared to the past have undergone tremendous changes. The micro-blog has constructed a new environment of interpersonal communication and exchange of ideas by means of equal participation, free expression, virtual identity, multiple roles, interactive multi-dimensional, rapid diffusion and other forms of information exchange. According to the survey, college students through micro-blogging concern information, $37.89 \%$ of current political hot, life information accounted for $44.21 \%$, philosophy, life perception accounted for $45.26 \%$, entertainment, sports news accounted for $47.37 \%, 42.11 \%$ psychological category. In the "attitude towards the use of micro-blogging", "to absorb multi-point view, I believe that the majority of" students accounted for $13 \%$, "rational analysis, multi-party views to express their views" accounted for 55 percent, "stick to their point of view Of the reference only "accounted for $27 \%$," difficult to distinguish between true and false, on their own ideas cause trouble "accounted for $5 \%$.

\section{The Problems of Art Education and Management in Colleges and Universities at Micro-Era}

The Problems in the Art Education Process in Colleges and Universities. The characteristics of art education in colleges and universities lie in the integration of creativity, subjectivity and individuality into the process of implementation. In particular, there are different approaches and requirements in teaching content, teaching mode, teaching plan and personnel training objectives. College art education is not only able to improve the overall quality of students, but also from different angles to improve its humanistic qualities. In many colleges and universities in China, are strengthening the popularization of art education. However, according to the structure of a survey, college students art education quality is not high, some students do not know the music, music appreciation of the level of China or the West less than a certain height, stay in hearing it This level; of Chinese or Western paintings, works of art also lack the basic ability to appreciate. In view of this situation, art education managers can combine the characteristics of the micro-era make full use of the network media and traditional classroom teaching, analysis of the status of art education, to find a solution to the problem.

The Problems in the Art Management Process in Colleges and Universities. Although the management of students has certain regularity, but in the actual normative process, due to the professional characteristics of student groups, student groups more obvious, the student groups affected by the impact of media information, there will be particularly difficult management issues. Art students have their own personality characteristics in the management of the difficulty, mainly from two aspects to solve this problem: on the one hand, our art students most of the cultural foundation is very weak, and weak cultural foundation of students Groups accounted for $60 \%$ of the total number of these students with professionalism in peacetime is only concerned about the professional development of other things in the school easy to have nothing to do with the attitude. On the other hand, the students of art majors are weak in self-discipline and lack of certain organizational discipline. Some students are naturally free, do not like to be too much constraint, so skipping, late and other disciplinary things have occurred and the phenomenon of long-term hanging Branch is very serious. $20 \%$ of the student's groups are often absent, $20 \%$ of the student groups are often late, more than $30 \%$ of the students linked to more than three subjects. Therefore, the micro-era art management cannot continue the traditional management model, how to innovate the management is also worthy of study. 


\section{The Current Personnel Training Objectives of Chinese College Art Quality Education}

From the different viewpoints, the university art quality education has the different talented person training goal in view of the present student's knowledge demand, the social development background, the talented person training present situation, the employment situation and so on.

First of all, students from the perspective of individual as a society, they have their own hobbies and special art knowledge and the pursuit of desire, etc., in particular, hopes to train themselves to become a moral good, knowledgeable, sound personality of the people. Institutions of higher learning are an important place for students to receive systematic knowledge and cultivate comprehensive literacy. They are responsible for providing other aspects of artistic knowledge while satisfying students' professional knowledge and specific skills.

Second, the various colleges and universities must also take full account of the national education authorities on the quality of education of students of the specified requirements and requirements, such as "National Art Education Development Plan" "on strengthening the national institutions of higher learning art education opinions" "High College The content of the quality education, the content of the art education, the disciplinary planning structure, the evaluation standard, the system and the model, not only the content system is rich, but also the problem involved is very broad, and has certain Guiding, systematic and authoritative features, which is an important criterion to be followed in the teaching of artistic accomplishment in colleges and universities.

Thirdly, art quality education in colleges and universities must also meet the needs of social work posts for the comprehensive quality of special talents. It has been said: the 21 st century national industrial development and breakthroughs will be concentrated in various industries to enhance the comprehensive level of art talent development and development. Only by cultivating a profound professional knowledge and technical level, but also a comprehensive artistic accomplishment of talent in order to achieve social innovation and upgrading of the industry, so as to promote the rapid development of the entire industry and enhance the national economy. To a certain extent, in addition to promoting the development of society has a great role, this is the university to enhance competitiveness, reflect the characteristics of running a school, increase employment, improve the visibility and influence of an important means, therefore, for social work personnel Satisfying needs is another important goal of personnel training in colleges and universities.

Finally, the college art quality education must also meet the rapid development of society and the goal of harmonious coexistence among different individuals. The rapid development of society, especially the continuous improvement of current scientific and technological level, makes people deeply realize that if the lack of appropriate learning ability, especially the rapid adaptability of the new environment, will soon be eliminated. And from the group composition point of view, society is composed of different individuals constitute a group organization, its orderly operation, on the one hand, people need to follow a certain social norms, on the other hand also need people's dedication, mutual help To long-term coexistence. In fact, the realization of this goal in addition to relying on social and legal norms, but also need knowledge and moral influence of colleges and universities, especially through artistic quality education, enlightening students' wisdom, cultivate sentiment, improve cultural accomplishment, so that they consciously follow Social norms, to fulfill the spirit of dedication and enhance the sense of collective responsibility.

\section{Measures to Increase the Art Education and Management Innovation in University at Micro Times}

Art Education Takes Cultivating Innovative Talents as the Main Target. Both art colleges and universities and art colleges and universities to strengthen the construction of art disciplines, training and artistic talent, are based on the traditional model of education on the basis of innovation to meet the growing needs of the development of cultural and artistic career. Colleges and universities should also rely on the characteristics of the school as a professional, for the school's art to make a reasonable professional positioning. With the advent of the media age, the ability of college students to learn and 
future development depends on whether they can better adapt to the development needs of society, in the display of self, show art, whether it can better enhance the students' society Responsibility. Micro-age is the era of widespread information, so in this kind of cultural communication process, we need a variety of artistic practice activities, so that students can fully cope with future social work, so that self-innovation ability can be improved. Therefore, colleges and universities should give full play to their advantages and highlight the cultivation of talents, focusing on the cultivation of cultural innovation of students, in particular, according to the regional development of cultural and creative industry trends out of a characteristic for the development of colleges and universities.

Increase the Construction of College Art Professional Teachers. In order to cultivate the innovative art talents, colleges and universities cannot do without the strong support of the teachers. Especially in the fast development of culture, the construction of teachers should stick to the principle of advancing with the times. Only by improving teachers' ideology, Groups of professional skills, and to strengthen the practical ability of teachers in order to fully adapt to the needs of talent development. Only by improving the ability of teachers can improve the professional skills of college students as a whole, and the improvement of teachers 'ability to innovate can improve the overall quality of college students' artistic innovation as a whole. In the process of improvement, teachers need to strengthen the students' artistic innovation and practice, and the construction of college art teachers is related to the effect of art education.

Establish An Open Education Management Philosophy. The school should be as much as possible to understand the network information, and strive to grasp the trend of public opinion, to guide the student group, take the initiative to identify the media information. Second, change the traditional education model, the use of advanced education methods and means. To class as a unit, to create a class belonging to the QQ group, in the QQ group to promote good communication between the student groups, as far as possible to pass out contains positive energy media information. At the same time, through flexible and diverse forms of online media interaction, including online counseling, student blog, SMS platform, BBS autonomous forums, the student groups in a timely manner personalized guidance and education. In addition, should also be combined with new media training, seminars, campus network, and strive to carry out publicity and education. These are flexible and diverse forms of teaching, so that college students through a positive way of learning to strengthen the experience of self-learning, through the creation of a virtual situation, to carry out web design contest, new media ethical debate contest, new media animation exhibition, DV shooting contest.

\section{Conclusion}

It is of great significance to strengthen the innovation of art education and management in colleges and universities under the background of micro times. Therefore, the government departments should take the initiative to assume the role of leader, introduced the relevant education policy. At the same time, colleges and universities should also maintain a high degree of consistency with the pace of government departments to develop innovative strategies to cultivate talented people, the teaching management departments of colleges and universities should explore a variety of ways to strengthen the arts education and management of innovative ideas.

\section{References}

[1] Jia Xinzhang, Li Jingyuan. Economic Daily, Vol. 6 (2014) No 53, p.25-26

[2] Peng Sue, Wang Yunhui, Wang Qunyong. Academic Research, Vol. 12 (2015) No 27, p.74-76

[3] Jing Jianfen. Science and Technology Management Research, Vol. 30 (2014) No 19, p.144-145

[4] Wang Kuailiang. Beijing Observation, Vol. 29 (2008) No 27, p.21-23

[5] Zhang Gongxu, Sun Jing. Education Exploration, Vol. 8 (2013) No 27, p.57-60 